\title{
Prevalence of Dual-Positivity for Both Hepatitis B e Antigen and Hepatitis B e Antibody Among Hospitalized Patients with Chronic Hepatitis B Virus Infection
}

\author{
Yuanyuan Liu (D) ${ }^{1,2}$ \\ Songmei $\mathrm{He}^{2}$ \\ Sichun Yin $\mathbb{D}^{2}$ \\ Qingyang Zhong ${ }^{2}$ \\ Jianbo Zhong ${ }^{2}$ \\ Xiaoyong Zhang' \\ Rong Fan' \\ Jinlin Hou ${ }^{1,3}$
}

'Department of Infectious Diseases, State Key Laboratory of Organ Failure Research, Guangdong Provincial Key Laboratory of Viral Hepatitis Research, Nanfang Hospital, Southern Medical University, Guangzhou, Guangdong, People's Republic of China; ${ }^{2}$ Department of Infectious Diseases, Dongguan People's Hospital, Dongguan, Guangdong, People's Republic of China; ${ }^{3}$ Hepatology Unit, Shenzhen Hospital, Southern Medical University, Shenzhen, Guangdong, People's Republic of China
Correspondence: Jinlin Hou

Department of Infectious Diseases, State Key Laboratory of Organ Failure Research, Guangdong Provincial Key Laboratory of Viral Hepatitis Research, Nanfang Hospital, Southern Medical University, Guangzhou, Guangdong, People's Republic of China

Tel +8620 6164194l

$\mathrm{Fax}+862062786530$

Email jlhousmu@I63.com
Objective: The detection of dual-positivity for both hepatitis B e antigen ( $\mathrm{HBeAg}$ ) and hepatitis B e antibody (anti-HBe) is not typically performed for patients with hepatitis $B$ virus (HBV). This cross-sectional study was designed to figure out the prevalence of dualpositivity for both $\mathrm{HBeAg}$ and anti-HBe (DEP) among hospitalized patients with chronic hepatitis B virus infection (C-HBVI).

Patients and Methods: Data from 2820 cases with C-HBVI from two centers in China were retrospectively analyzed. Univariate and multivariate logistic regression analyses were undertaken to identify the risk factors for liver fibrosis (LF) and acute-on-chronic liver failure (ACLF).

Results: There were 165 (5.9\%), 688, and 1903 patients in DEP, HBeAg+/anti-HBe-, and $\mathrm{HBeAg}-/$ anti-HBe+ groups, respectively. The DEP patients' median age was 43.6 years old and $71.5 \%$ of them were male. They had higher levels of alanine transaminase, total bilirubin, and international normalized ratio. Furthermore, DEP cases had a higher proportion of liver cirrhosis, and it was associated with non-invasive testing of LF, including aspartate transaminase (AST)-to-platelet ratio index (APRI) $>1.5$ (odds ratio $(\mathrm{OR})=1.96,95 \%$ confidence interval $(\mathrm{CI}): 1.27-3.03, P=0.002)$ and fibrosis-4 (FIB-4) score $>1.45$ (OR $=$ $2.07,95 \%$ CI: $1.28-3.34, P=0.003$ ). DEP also contributed to the elevated risk of ACLF (OR $=4.80,95 \%$ CI: 2.02-11.39, $P<0.001)$.

Conclusion: DEP cases are at higher risks of LF and ACLF than other patients with HBV infection. A fast diagnosis and an active monitoring of liver diseases for DEP patients are extremely vital.

Keywords: hepatitis B e antigen, hepatitis B e antibody

\section{Introduction}

Hepatitis B virus infection (HBVI) is a worldwide health concern, and nearly 240 million HBVI cases and 650 thousand HBV-related deaths occur annually. ${ }^{1}$ In China, there are near 30 million chronic hepatitis B (CHB) cases, of whom 1 million cases have liver cirrhosis and 0.3 million have HBV-associated hepatocellular carcinoma (HCC). ${ }^{2}$

The detection of dual-positivity for both hepatitis $\mathrm{B}$ e antigen and hepatitis $\mathrm{B}$ e antibody (DEP) is not typically performed for CHB patients. To date, relevant researches have pointed out that the prevalence of DEP is $0.2-2.6 \%$ 
in $\mathrm{CHB}$ cases and $10.4 \%$ in $\mathrm{CHB}$ cases in the immuneactive phase (I-AP). ${ }^{3-5}$ It has been speculated that during the transition between positivity for $\mathrm{HBeAg}$ and positivity for anti-HBe, the serologic markers might achieve an optimal rate, making them simultaneously detectable.

According to the existence of $\mathrm{HBeAg}$, the viral load of HBV-DNA, and the extent of liver damage, CHB can be divided into the following phases: immune-tolerant phase, I-AP, and inactive phase. ${ }^{6}$ DEP patients can theoretically be in the immune-tolerant phase and I-AP, while the majority of them are found to be in the I-AP. $^{3}$ A previous research demonstrated that, among CHB cases in the I-AP, DEP cases had higher levels of alanine aminotransferase (ALT) and total bilirubin (TBIL) than other CHB cases, ${ }^{4}$ indicating the influence of DEP on the progression of liver diseases (LDs). However, the clinical and virological features and mechanisms underlying DEP among chronic HBVI (C-HBVI) cases have remained elusive.

In this cross-sectional study, we attempted to ascertain the prevalence of DEP among hospitalized patients with $\mathrm{C}$-HBVI, and to figure out the clinical relevance of DEP and LDs in two medical centers in China.

\section{Patients and Methods}

\section{Patients}

A total of 3689 hospitalized cases with C-HBVI (age $>18$ years old) who were admitted to the Dongguan People's Hospital (Dongguan, China; from 2014 (January) to 2018 (December)) and Nanfang Hospital (Guangzhou, China; from 2016 (January) to 2016 (December)) were recruited. The existence of hepatitis B surface antigen (HBsAg) in serum ( $\geq 6$ months) was utilized to define HBVI. Cases coinfected with other viruses (eg, hepatitis $\mathrm{C}$ virus, hepatitis $D$ virus, and human immunodeficiency virus) $(n=109)$ were ruled out. Those cases with other causes of hepatitis (eg, drug-induced LDs, autoimmune hepatitis, alcoholic LDs, etc.) $(n=47)$ and HCC $(n=713)$ were not involved. In the remaining 2820 cases, $5.9 \%$ (165/2820) were DEP cases. Those cases with HBeAg-negative and anti-HBe-negative (n $=64$ ) were excluded from additional analyses except for prevalence analyses during recruitment (Figure 1).

\section{Definitions}

Characterization of acute-on-chronic liver failure (ACLF) cases was carried out by serum bilirubin level $\geq 5 \mathrm{mg} / \mathrm{dL}$ and coagulopathy (international normalized ratio (INR) $\geq 1.5$ or prothrombin activity $<40 \%$ ) complicated by

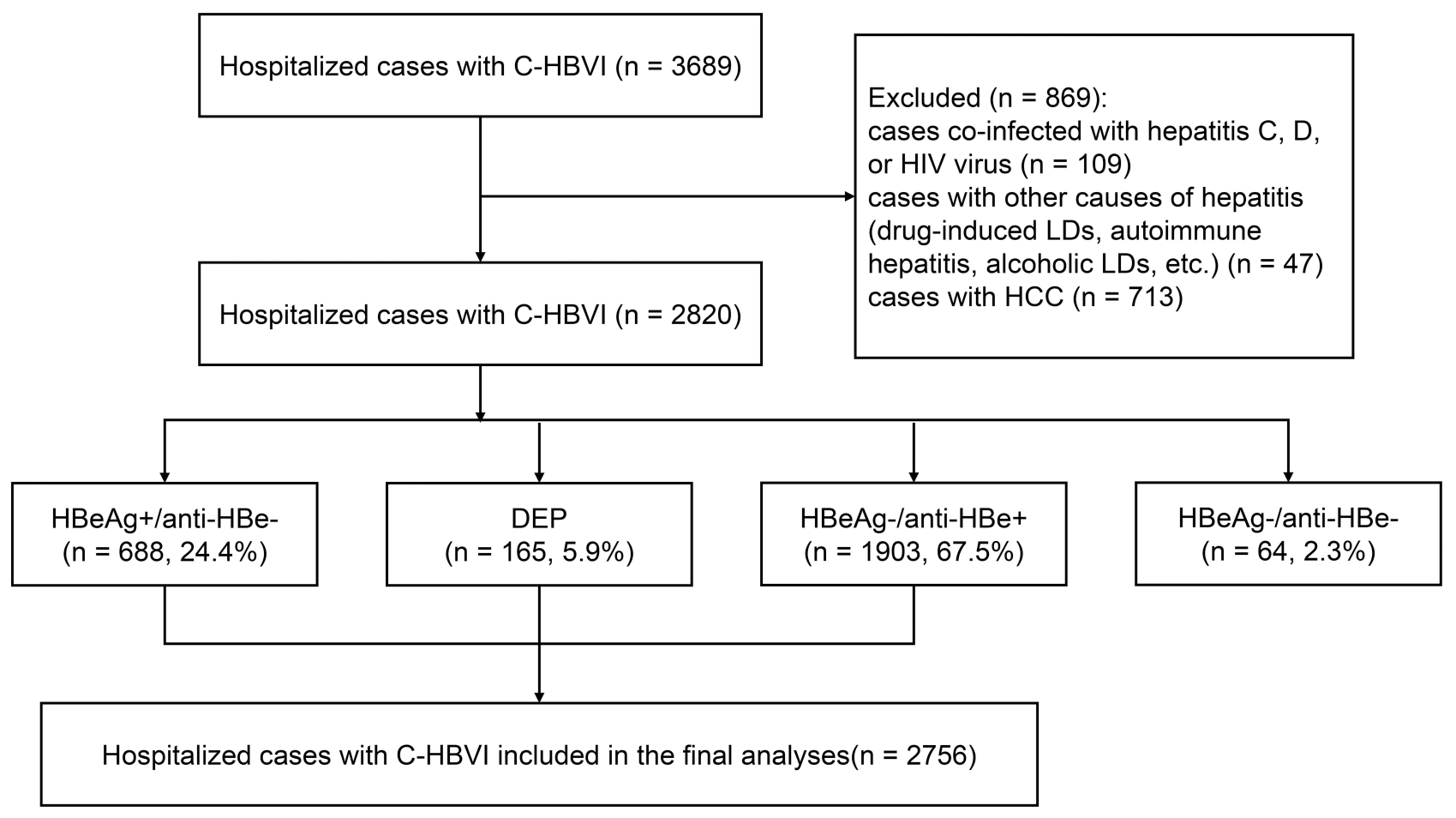

Figure I Flowchart of study design.

Abbreviations: DEP, dual-positivity for both hepatitis $B$ e antigen and hepatitis $B$ e antibody; $C-H B V I$, chronic hepatitis $B$ virus infection; $H B V$, hepatitis $B$ virus; $H B e A g$, hepatitis B e antigen; anti-HBe, hepatitis B e antibody; HIV, human immunodeficiency virus. 
clinical ascites and/or encephalopathy for within 4 weeks. ${ }^{7}$ The normal values of biochemical indices of liver function are as follows: ALT (male $<50 \mathrm{U} / \mathrm{L}$, female $<40 \mathrm{U} / \mathrm{L}$ ), aspartate transaminase (AST) (male $<40 \mathrm{U} / \mathrm{L}$, female $<35 \mathrm{U} / \mathrm{L})$, and absolute neutrophil count $\left(6.4 \times 10^{9} / \mathrm{L}\right)$. Characterization of immune-tolerant phase was undertaken on the basis of HBeAg-positive with a high HBV DNA titer (typically $>10^{6} \mathrm{IU} / \mathrm{mL}$ ) and a normal ALT level. I-AP was characterized by an intermittently or persistently elevated ALT level and a serum HBV DNA titer $>2 \times 10^{4} \mathrm{IU} /$ $\mathrm{mL}$ in those cases with $\mathrm{HBeAg}$-positive $\mathrm{CHB}$ and $>2 \times 10^{3}$ $\mathrm{IU} / \mathrm{mL}$ in those cases with HBeAg-negative CHB, according to the $2018 \mathrm{HBV}$ guidelines published by the American Association for the Study of Liver Diseases. ${ }^{6}$ Virological response was defined as a serum HBV DNA titer lower than the lower limit of detection during treatment. Cirrhosis and decompensated cirrhosis were characterized by the results of ultrasonography, computed tomography (CT) and clinical criteria, indicating portal hypertension, such as ascites and esophageal and gastric varices. A moderate alcohol consumption level was defined as $>40 \mathrm{~g} /$ day.

We used AST-to-platelet ratio index (APRI) and fibrosis-4 (FIB-4) scores to appraise liver fibrosis (LF), and these scores were calculated as described in advance. ${ }^{8,9}$

\section{Serology Testing}

Serologic markers for HBV, including HBsAg, anti-HBs, $\mathrm{HBeAg}$, and anti-HBe, were measured using the DiaSorin Liaison-XL (DiaSorin, Saluggia, Italy) and ARCHITECT i2000SR (Abbott, Chicago, IL, USA) platforms. According to the upper limit of the instruments, HBsAg $>150 \mathrm{IU} / \mathrm{mL}$ was used as the cut-off value for measuring high level of HBsAg because the HBsAg concentration in some cases had not been further diluted. The measurement of HBV DNA levels was undertaken using the Daan test (Daan Gene Co., Ltd. Affiliated to Sun Yat-sen University, Guangzhou, China) and Roche COBAS TaqMan HBV Test kit (Roche Diagnostics, Branchburg, NJ, USA) using the HBV DNA detection lower limits of 500 and $20 \mathrm{IU} / \mathrm{mL}$, respectively. In addition, $\mathrm{HBeAg}$ titer $>1.0 \mathrm{~S} / \mathrm{CO}$ and anti-HBe titer $<1.0 \mathrm{~S} /$ $\mathrm{CO}$ were considered as positive on the basis of protocols released by the manufacturers. Other laboratory tests were undertaken at local laboratories according to the standard procedures.

\section{Statistical Analysis}

The presentation of continuous variables was in the form of mean \pm standard deviation (SD), and their analysis was undertaken using the Student's $t$-test or the Mann-Whitney $U$-test. The expression of categorical variables was in form of percentage, and their analysis was carried out using the Chi-square test or the Fisher's exact test. We also employed univariate and multivariate logistic regression analyses (termed as ULS and MLS analyses, respectively) with a stepwise backward procedure to examine the association of DEP with LF and ACLF. The cutoff values of FIB-4 $>1.45$ and APRI $>1.5$ were used to ascertain the absence of LF. ${ }^{10}$ The prevalence of DEP was reported with $95 \%$ confidence interval $(95 \% \mathrm{CI})$. We set the level of significance to $\mathrm{P}<0.05$. The SPSS 22.0 software (IBM Corp., Armonk, NY, USA) was utilized to statistically analyze the data.

\section{Results}

A total of 2756 cases with C-HBVI fulfilled the study criteria (Figure 1). Their demographic, serological, and clinical features are presented in Table 1 and S1.

\section{Demographic Features of DEP Cases and Prevalence of DEP}

Among C-HBVI cases, there were 165 DEP cases. After excluding 64 cases with $\mathrm{HBeAg}$ - and anti-HBe-negative, the remaining 2591 cases (control group) were assigned into 2 subgroups based on the results of a serology test: $\mathrm{HBeAg}$ //anti-HBe- group $(\mathrm{n}=688)$ and $\mathrm{HBeAg}$-/anti$\mathrm{HBe}+$ group $(\mathrm{n}=1903)$. Besides, $78(10.8 \%), 281$ $(38.9 \%)$, and $363(50.3 \%)$ cases $(\mathrm{n}=722)$ in the I-AP were allocated to DEP, $\mathrm{HBeAg}+/$ anti-HBe-, and $\mathrm{HBeAg}-/$ anti-HBe+ groups, respectively (Table 2 and $\underline{\mathrm{S} 2}$ ). In total, $71.5 \%(118 / 165)$ of the DEP cases were male, which was similar to the proportions of those who were in $\mathrm{HBeAg}$ +/anti-HBe- (64.7\%) and HBeAg-/anti-HBe+ (67.9\%) groups. DEP cases tended to be older than $\mathrm{HBeAg}+/$ antiHBe- cases ( $43.6 \pm 11.8$ versus $41.7 \pm 13.9$ years old, $P=$ $0.085)$ and were markedly younger than $\mathrm{HBeAg}$-/anti-HBe + cases $(43.6 \pm 11.8$ versus $52.3 \pm 13.2$ years old, $P=$ $0.001)$.

The prevalence of DEP was $8.0 \%$ (95\% CI: $6.4-9.6 \%)$ and 4.4\% (95\% CI: 3.4-5.4\%) among cases who aged $<45$ and $\geq 45$ years old, respectively $(\mathrm{P}<0.001)$ (Table 3 and Figure 2). The prevalence of DEP among cases in the I-AP was $10.7 \%$ (95\% CI: $8.5-13.0 \%$ ). Additionally, $56.9 \%$ 
Table I Demographic, Serological, and Clinical Features of DEP, HBeAg+/Anti-HBe-, and HBeAg-/Anti-HBe+ Cases with C-HBVI

\begin{tabular}{|c|c|c|c|}
\hline & DEP & HBeAg+/Anti-HBe- & HBeAg-/Anti-HBe+ \\
\hline Total (n) & 165 & 688 & 1903 \\
\hline Gender: male (n, \%) & II 8 (7I.5\%) & 445 (64.7\%) & 1292 (67.9\%) \\
\hline Age (years old) & $43.6 \pm 11.8$ & $41.7 \pm 13.9$ & $52.3 \pm 13.2$ \\
\hline Treatment history (n, \%) & $45(27.3 \%)$ & 178 (25.9\%) & $439(23.1 \%)$ \\
\hline Alcohol consumption (n, \%) & $6(3.6 \%)$ & $18(2.6 \%)$ & 84 (4.4\%) \\
\hline ALT (U/L) & $83.00(31.30-314.80)$ & $58.25(27.08-224.93)$ & $31.00(19.40-65.33)$ \\
\hline AST (U/L) & $71.80(38.95-220.40)$ & $57.75(34.00-\mid 42.23)$ & $37.60(26.20-69.23)$ \\
\hline TBIL $(\mu \mathrm{mol} / \mathrm{L})$ & $21.50(13.80-70.85)$ & $18.35(12.60-32.20)$ & $16.00(11.50-26.33)$ \\
\hline TBIL $\geq 34.2 \mu \mathrm{mol} / \mathrm{L}(\mathrm{n}, \%)$ & $60(36.4 \%)$ & $160(23.3 \%)$ & 350 (I8.4\%) \\
\hline ALB $(g / L)$ & $35.60(31.40-39.80)$ & $38.20(34.0 I-4 I .69)$ & $39.19(33.61-42.97)$ \\
\hline INR & $1.15(1.03-1.39)$ & $1.07(1.00-1.20)$ & $1.04(0.97-1.18)$ \\
\hline INR $\geq 1.5(\mathrm{n}, \%)$ & 31 (I8.8\%) & 57 (8.3\%) & $198(10.4 \%)$ \\
\hline PLT ( $\left.10^{9} / \mathrm{L}\right)$ & $154.50(107.00-213.75)$ & $178.00(122.75-227.00)$ & $180.00(121.00-232.00)$ \\
\hline $\mathrm{HBsAg}>\mathrm{I} 50 \mathrm{IU} / \mathrm{mL}(\mathrm{n}, \%)$ & $125(75.8 \%)$ & $617(89.7 \%)$ & 1205 (63.3\%) \\
\hline APRI & $\mathrm{I} .66(0.6 \mathrm{I}-4.95)$ & I.I5 (0.46-2.82) & $0.62(0.34-1.57)$ \\
\hline APRI $\geq 1.5(n, \%)$ & $86(52.1 \%)$ & $269(39.1 \%)$ & 487 (25.6\%) \\
\hline FIB-4 & $2.56(1.48-4.98)$ & $1.83(1.00-3.92)$ & $2.11(1.24-4.30)$ \\
\hline FIB-4 > I.45 (n, \%) & $126(76.4 \%)$ & $416(60.5 \%)$ & $129 \mid(67.8 \%)$ \\
\hline Cirrhosis (n, \%) & $54(32.7 \%)$ & $157(22.8 \%)$ & $472(24.8 \%)$ \\
\hline Decompensated cirrhosis (n, \%) & $38(23.0 \%)$ & 89 (I2.9\%) & 299 (I5.7\%) \\
\hline $\operatorname{ACLF}(n, \%)$ & 13 (7.9\%) & II (1.6\%) & $56(2.9 \%)$ \\
\hline HBV DNA (n) & 137 & 519 & 1232 \\
\hline HBV DNA Positive (n, \%) & $126(92.0 \%)$ & 444 (85.6\%) & 717 (58.2\%) \\
\hline HBV DNA $\left(\log _{10} \mathrm{IU} / \mathrm{mL}\right)$ & $5.38(4.03-6.59)$ & $6.00(3.94-7.27)$ & $2.92(2.70-4.70)$ \\
\hline$<4(\mathrm{n}, \%)$ & $32(23.4 \%)$ & $133(25.6 \%)$ & $828(67.2 \%)$ \\
\hline$\geq 4$ and $<6(\mathrm{n}, \%)$ & $62(45.2 \%)$ & $127(24.5 \%)$ & $270(21.9 \%)$ \\
\hline$\geq 6$ and $<8(\mathrm{n}, \%)$ & $31(22.6 \%)$ & 199 (38.3\%) & $117(9.5 \%)$ \\
\hline$\geq 8(\mathrm{n}, \%)$ & $12(8.8 \%)$ & $60(11.6 \%)$ & 17 (I.4\%) \\
\hline Immune-tolerant (n, \%) & $5(3.6 \%)$ & $82(15.8 \%)$ & \\
\hline Immune-active (n, \%) & 78 (56.9\%) & $281(54.1 \%)$ & $363(29.5 \%)$ \\
\hline
\end{tabular}

Notes: $\mathrm{PI}$-value for $\mathrm{HBeAg}+/ \mathrm{anti}-\mathrm{HBe}+$ group and $\mathrm{HBeAg}+/ \mathrm{anti}-\mathrm{HBe}-$ group; $\mathrm{P} 2$-value for $\mathrm{HBeAg}+/ \mathrm{anti}-\mathrm{HBe}+$ group and $\mathrm{HBeAg}$-/anti-HBe+ group; $\mathrm{P}$-value for all groups. Abbreviations: DEP, dual-positivity for both hepatitis $B$ e antigen and hepatitis $B$ e antibody; $C-H B V I$, chronic hepatitis $B$ virus infection, HBeAg, hepatitis $B$ e antigen; anti-HBe, hepatitis B e antibody; $\mathrm{HBsAg}$, hepatitis B surface antigen; ALT, alanine aminotransferase; AST, aspartate transaminase; TBIL, total bilirubin; ALB, albumin; INR, international normalized ratio; PLT, platelet; FIB, fibrinogen; APRI, AST-to-platelet ratio index; FIB-4, fibrosis-4; ACLF, acute-on-chronic liver failure.

(78/137) of the cases in the DEP group were in the I-AP, which was similar to the proportion of cases in the $\mathrm{HBeAg}$ +/anti-HBe- group $(54.1 \%, \mathrm{P}=0.559)$, while it was remarkably higher than that in the $\mathrm{HBeAg}-/$ anti-HBe+ group $(29.5 \%, \mathrm{P}<0.001)$.

\section{Serological and Clinical Features of DEP Patients}

The median ALT and AST levels in the DEP group (83.00 and $71.80 \mathrm{U} / \mathrm{L}$ ) were remarkably higher than those in the $\mathrm{HBeAg}+/$ anti-HBe- $(P=0.024$ and 0.014 , respectively $)$ and HBeAg-/anti-HBe+ groups (both $P<0.001$ ). The TBIL level in the DEP group was notably higher than that in the HBeAg+/anti-HBe- (21.50 versus $18.35 \mu \mathrm{mol} /$
$\mathrm{L}, P=0.011)$ and $\mathrm{HBeAg}-/$ anti-HBe+ groups $(16.00 \mu \mathrm{mol} /$ $\mathrm{L}, P<0.001)$. We figured out a greater proportion of cases with a TBIL level $\geq 34.2 \mu \mathrm{mol} / \mathrm{L}$ in the DEP group (36.4\%) than that in the HBeAg+/anti-HBe- $(23.3 \%)$ and HBeAg-/ anti-HBe+ groups $(18.4 \%)(P<0.001)$. The median INR in the DEP group was 1.15 , which was markedly higher than that in the HBeAg+/anti-HBe- $(1.07, P<0.001)$ and $\mathrm{HBeAg}$-/anti-HBe+ groups $(1.04, P<0.001)$. The median platelet (PLT) count in the DEP group $\left(154.50 \times 10^{9} / \mathrm{L}\right)$ was lower than that in the $\mathrm{HBeAg}+/ \mathrm{anti}-\mathrm{HBe}-$ and $\mathrm{HBeAg}$-/anti-HBe+ groups $(P=0.027$ and 0.005 , respectively). In the I-AP, the proportions of TBIL $\geq 34.2 \mu \mathrm{mol} / \mathrm{L}$ (48.7\%) and INR $\geq 1.5$ (23.1\%) in the DEP group were noticeably higher than those in the $\mathrm{HBeAg}+/$ anti-HBe- 
Table 2 Demographic, Serological, and Clinical Features of DEP, HBeAg+/Anti-HBe-, and HBeAg-/Anti-HBe+ Cases with C-HBVI in the Immune-Active Phase

\begin{tabular}{|c|c|c|c|}
\hline & DEP & HBeAg+/Anti-HBe- & HBeAg-/Anti-HBe+ \\
\hline Total (n) & $78(10.8 \%)$ & $28 \mathrm{I}(38.9 \%)$ & $363(50.3 \%)$ \\
\hline Gender: male (n, \%) & $64(82.1 \%)$ & $206(73.3 \%)$ & $27 \mid(74.7 \%)$ \\
\hline Age (years old) & $39.00(33.75-47.00)$ & $36.00(30.00-44.00)$ & $49.00(41.00-59.00)$ \\
\hline Treatment history (n, \%) & 19 (24.4\%) & $59(21.0 \%)$ & 68 (I8.7\%) \\
\hline ALT (U/L) & $261.65(107.25-698.83)$ & $229.60(85.40-508.20)$ & $157.00(71.80-4 \mid 2.00)$ \\
\hline AST (U/L) & $178.20(88.48-4 \mid 4.10)$ & 140.00 (7I.00-26I.05) & $112.10(64.00-268.60)$ \\
\hline TBIL $(\mu \mathrm{mol} / \mathrm{L})$ & 30.85 (14.50-136.35) & $21.80(14.80-49.80)$ & $24.40(14.00-87.30)$ \\
\hline TBIL $\geq 34.2 \mu \mathrm{mol} / \mathrm{L}$ & 38 (48.7\%) & 99 (35.2\%) & 146 (40.2\%) \\
\hline ALB $(g / L)$ & $34.85(31.65-38.13)$ & $37.25(33.53-40.10)$ & $36.45(31.65-41.03)$ \\
\hline INR & $1.19(1.07-1.47)$ & $1.10(1.03-1.24)$ & $1.15(1.03-1.44)$ \\
\hline INR $\geq 1.5(\mathrm{n}, \%)$ & $18(23.1 \%)$ & 24 (8.5\%) & $8 \mathrm{I}(22.3 \%)$ \\
\hline $\operatorname{PLT}\left(10^{9} / \mathrm{L}\right)$ & $150.00(102.80-207.10)$ & $171.00(125.90-222.00)$ & $162.00(\mid 10.30-205.50)$ \\
\hline $\mathrm{HBsAg}>\mathrm{I} 50 \mathrm{IU} / \mathrm{mL}(\mathrm{n}, \%)$ & 55 (70.5\%) & 252 (89.7\%) & $276(76.0 \%)$ \\
\hline HBV DNA ( $\left.\log _{10} 1 \mathrm{IU} / \mathrm{mL}\right)$ & $6.14(5.28-7.27)$ & $6.89(5.91-7.74)$ & $5.43(4.38-6.39)$ \\
\hline$<6(\mathrm{n}, \%)$ & 38 (48.7\%) & 81 (28.8\%) & $242(66.7 \%)$ \\
\hline$\geq 6$ and $<8(\mathrm{n}, \%)$ & 28 (35.9\%) & 148 (52.7\%) & 105 (28.9\%) \\
\hline$\geq 8(\mathrm{n}, \%)$ & $12(15.4 \%)$ & $52(18.5 \%)$ & $16(4.4 \%)$ \\
\hline APRI & $4.57(1.94-8.97)$ & $2.37(1.18-5.00)$ & $2.26(1.02-5.46)$ \\
\hline APRI $\geq 1.5(n, \%)$ & 60 (76.9\%) & I8I (64.4\%) & $225(62.0 \%)$ \\
\hline FIB-4 & $2.86(1.89-5.94)$ & $2.11(1.23-3.97)$ & $3.07(1.74-6.38)$ \\
\hline FIB-4 > I.45 (n, \%) & 67 (85.9\%) & $188(66.9 \%)$ & $300(82.6 \%)$ \\
\hline Cirrhosis (n, \%) & $24(30.8 \%)$ & $5 \mathrm{I}(18.2 \%)$ & $107(29.5 \%)$ \\
\hline Decompensated cirrhosis (n, \%) & $16(20.5 \%)$ & 25 (8.9\%) & 65 (17.9\%) \\
\hline $\operatorname{ACLF}(n, \%)$ & $8(10.3 \%)$ & $6(2.1 \%)$ & $29(8.0 \%)$ \\
\hline
\end{tabular}

Notes: $\mathrm{PI}$-value for $\mathrm{HBeAg}+/ \mathrm{anti}-\mathrm{HBe}+$ group and $\mathrm{HBeAg}+/ \mathrm{anti}-\mathrm{HBe}$ - group; $\mathrm{P} 2$-value for $\mathrm{HBeAg}+/ \mathrm{anti}-\mathrm{HBe}+$ group and $\mathrm{HBeAg}$-/anti-HBe+ group; $\mathrm{P}$-value for all groups. Abbreviations: DEP, dual-positivity for both hepatitis $B$ e antigen and hepatitis $B$ e antibody; $C-H B V I$, chronic hepatitis $B$ virus infection; $H B e A g$, hepatitis $B$ e antigen; anti$\mathrm{HBe}$, hepatitis B e antibody; HBsAg, hepatitis B surface antigen; ALT, alanine aminotransferase; AST, aspartate transaminase; TBIL, total bilirubin; ALB, albumin; INR, international normalized ratio; PLT, platelet; FIB, fibrinogen; APRI, AST-to-platelet ratio index; FIB-4, fibrosis-4; ACLF, acute-on-chronic liver failure.

group $(P<0.05)$, while no significant difference was identified in the mentioned proportions between the DEP and $\mathrm{HBeAg}$-/anti-HBe+ groups.

The proportion of HBsAg $>150 \mathrm{IU} / \mathrm{mL}$ in the DEP group $(75.8 \%, 125 / 165)$ was in the range of $63.3 \%-89.7 \%$, as presented in the $\mathrm{HBeAg}+/$ anti-HBe- $(89.7 \%, P<0.001)$ and HBeAg-/anti-HBe+ groups $(63.3 \%, P=0.001)$. The HBV DNA level in the DEP group (median, $5.38 \log _{10} \mathrm{IU} /$ $\mathrm{mL}$; range, $4.03-6.59 \log _{10} \mathrm{IU} / \mathrm{mL}$ ) was noticeably lower than that in the $\mathrm{HBeAg}+/$ anti-HBe- group and greater than that in the $\mathrm{HBeAg}$-/anti-HBe+ group. In the majority of DEP cases, the HBV DNA level ranged from 4 to $6 \log _{10}$ $\mathrm{IU} / \mathrm{mL}(45.2 \%)$, while the HBV DNA level was in the range of 6 to $8 \log _{10} \mathrm{IU} / \mathrm{mL}$ in the majority of $\mathrm{HBeAg}$ +/anti-HBe- cases (38.3\%), and the HBV DNA level was dominantly $<4 \log _{10} \mathrm{IU} / \mathrm{mL}$ among $\mathrm{HBeAg}$ - cases $(67.2 \%)$ (Figure 3A). In the I-AP, the median HBV DNA level in the DEP group (6.14 $\log _{10} \mathrm{IU} / \mathrm{mL}$; range, 5.28-7.27 $\log _{10}$ $\mathrm{IU} / \mathrm{mL}$ ) was lower than that in the $\mathrm{HBeAg}+/$ anti-HBe- group (6.89 $\log _{10} \mathrm{IU} / \mathrm{mL}, P=0.001$ ) and higher than that in the $\mathrm{HBeAg}$-/anti-HBe+ group $\left(5.43 \log _{10} \mathrm{IU} / \mathrm{mL}\right.$, $\mathrm{P}<0.001$ ) (Table 2 and $\underline{\mathrm{S} 2}$; Figure 3B).

\section{Proportions of LF and ACLF in DEP Patients}

The median APRI score in the DEP group was 1.66 (range, 0.61-4.95), which was remarkably higher than that in the HBeAg+/anti-HBe- (median, 1.15; $P=0.002$ ) and $\mathrm{HBeAg}-/$ anti-HBe+ groups $(0.62, P<0.001)$. The median FIB-4 score in the DEP group (2.56; range, 1.48-4.98) was noticeably higher than that in the HBeAg +/anti-HBe- group (median, 1.83; $P=0.001$ ).

Among cases in the I-AP, the median APRI score in the DEP group (4.57; range, 1.94-8.97) was markedly higher than that in the $\mathrm{HBeAg}+/$ anti-HBe- (median, 2.37; $P=$ 0.002 ) and $\mathrm{HBeAg}$-/anti-HBe+ groups (median, 2.26; $P=$ 0.003 ) (Table 2 and S2). The median FIB-4 score in the DEP group (2.86; range, 1.89-5.94) in the I-AP was 
Table 3 Prevalence of DEP Among C-HBVI Cases

\begin{tabular}{|c|c|c|c|c|c|c|c|c|c|}
\hline & \multirow{2}{*}{$\frac{\text { Overall }}{\mathbf{N}}$} & \multicolumn{2}{|r|}{ DEP } & \multicolumn{2}{|c|}{ HBeAg+/Anti-HBe- } & \multicolumn{2}{|c|}{ HBeAg-/Anti-HBe+ } & \multicolumn{2}{|c|}{ HBeAg-/Anti-HBe- } \\
\hline & & $\mathbf{n}$ & $\begin{array}{c}\text { Prevalence (\%) } \\
(95 \% \mathrm{Cl})\end{array}$ & $\mathbf{n}$ & $\begin{array}{c}\text { Prevalence (\%) } \\
\quad(95 \% \mathrm{Cl})\end{array}$ & $\mathbf{n}$ & $\begin{array}{c}\text { Prevalence (\%) } \\
(95 \% \mathrm{Cl})\end{array}$ & $\mathbf{n}$ & $\begin{array}{c}\text { Prevalence (\%) } \\
\quad(95 \% \mathrm{Cl})\end{array}$ \\
\hline \multicolumn{10}{|l|}{ Age (years old) } \\
\hline$<45$ & 1134 & 91 & $8.0(6.4-9.6)$ & 450 & $39.7(36.8-42.5)$ & 573 & $50.5(47.6-53.4)$ & 20 & $1.8(1.0-2.5)$ \\
\hline$\geq 45$ & 1686 & 74 & $4.4(3.4-5.4)$ & 238 & I4.I (I2.5-15.8) & 1330 & $78.9(76.9-80.8)$ & 44 & $2.6(1.8-3.4)$ \\
\hline \multicolumn{10}{|l|}{ Gender } \\
\hline Male & 1898 & 118 & $6.2(5.1-7.3)$ & 445 & $23.4(21.5-25.4)$ & 1292 & $68.1(66.8-70.7)$ & 43 & $2.3(1.6-2.9)$ \\
\hline Female & 922 & 47 & $5.1(3.7-6.5)$ & 243 & $26.4(23.5-29.2)$ & 611 & $66.3(63.2-69.3)$ & 21 & $2.3(1.3-3.2)$ \\
\hline \multicolumn{10}{|l|}{ Treatment } \\
\hline $\begin{array}{l}\text { Treatment } \\
\text { naive }\end{array}$ & 2129 & 120 & $5.6(4.7-6.6)$ & 510 & $24.0(22.1-25.8)$ & 1464 & $68.8(66.8-70.7)$ & 35 & $1.6(1.1-2.2)$ \\
\hline $\begin{array}{l}\text { Treatment } \\
\text { experienced }\end{array}$ & 691 & 45 & $6.5(4.7-8.4)$ & 178 & $25.8(22.5-29.0)$ & 439 & $63.5(59.9-67.1)$ & 29 & $4.2(2.7-5.7)$ \\
\hline \multicolumn{10}{|l|}{$\begin{array}{l}\text { Immune } \\
\text { statement }\end{array}$} \\
\hline $\begin{array}{l}\text { Immune- } \\
\text { tolerant }\end{array}$ & 87 & 5 & $5.7(0.9-10.6)$ & 82 & 94.3 (89.4-99.1) & & & & \\
\hline Immune-active & 727 & 78 & $10.7(8.5-13.0)$ & 281 & $38.7(35.1-42.2)$ & 363 & $49.9(46.3-53.6)$ & 5 & $0.7(0.1-1.3)$ \\
\hline
\end{tabular}

Abbreviations: DEP, dual-positivity for both hepatitis B e antigen and hepatitis B e antibody; C-HBVI, chronic hepatitis B virus infection; HBeAg, hepatitis B e antigen; anti$\mathrm{HBe}$, hepatitis B e antibody.

higher than that in the HBeAg+/anti-HBe- group (median, 2.11; $P=0.001$ ), while we did not identify a significant difference in FIB-4 score between the DEP and HBeAg-/ anti-HBe+ groups.
The proportions of cirrhosis and decompensated cirrhosis in the DEP group (32.7\% and $23.0 \%$, respectively) were noticeably higher than those in the other two groups (HBeAg+/anti-HBe-, $22.8 \%$ and $12.9 \%, \mathrm{P}=0.008$ and

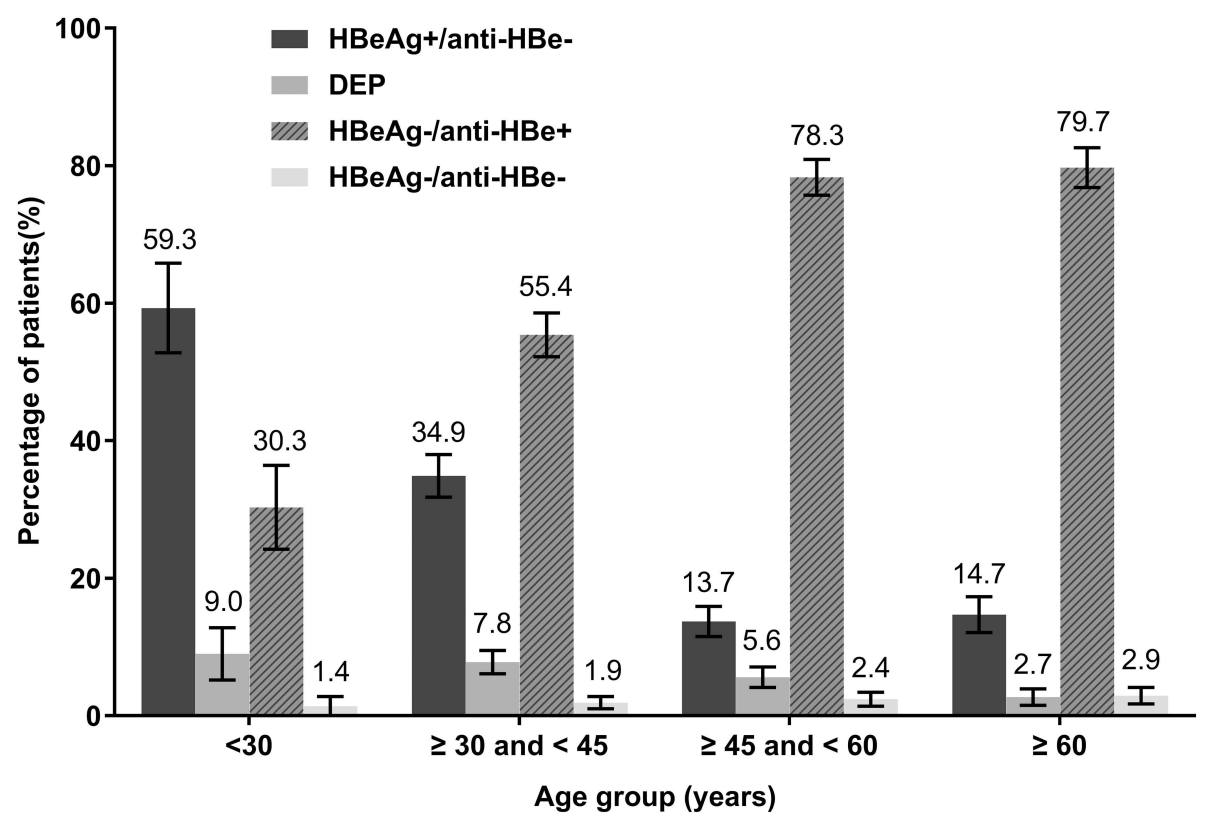

Figure 2 Prevalence of DEP among C-HBVI cases in age-dependent groups.

Abbreviations: DEP, dual-positivity for both hepatitis $B$ e antigen and hepatitis $B$ e antibody; $C-H B V I$, chronic hepatitis $B$ virus infection; $H B V$, hepatitis $B$ virus; $H B e A g$, hepatitis B e antigen; anti-HBe, hepatitis B e antibody. 
A

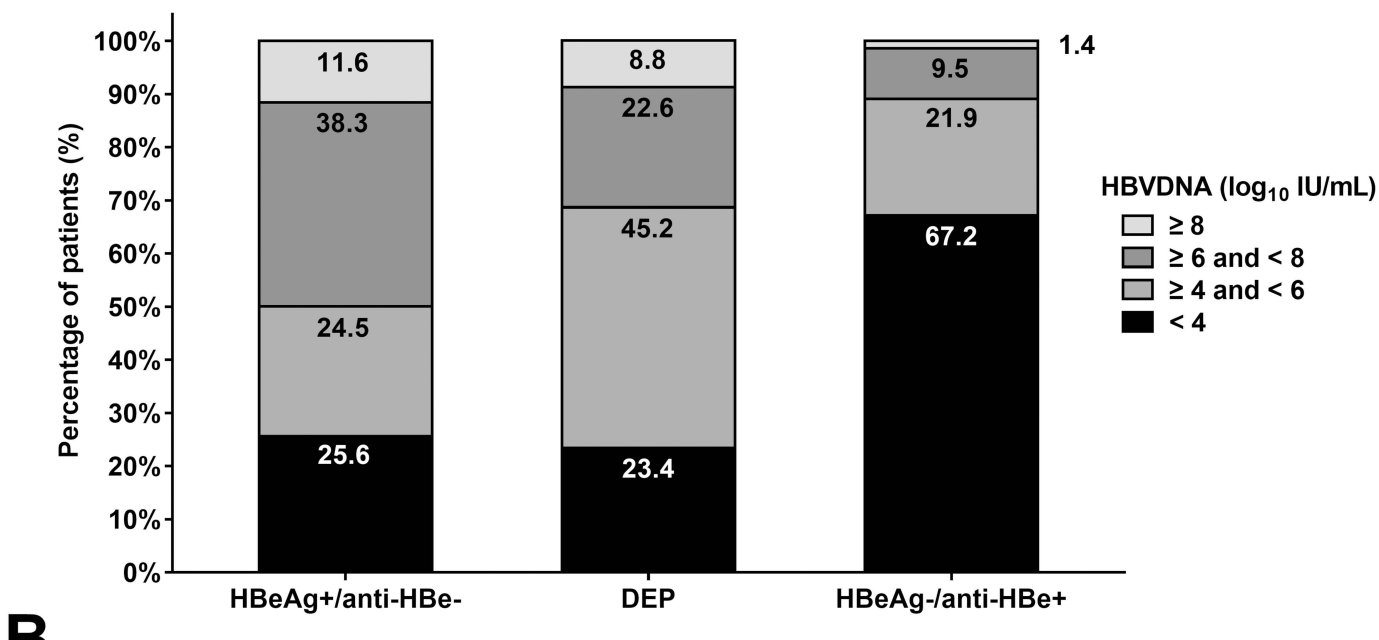

B

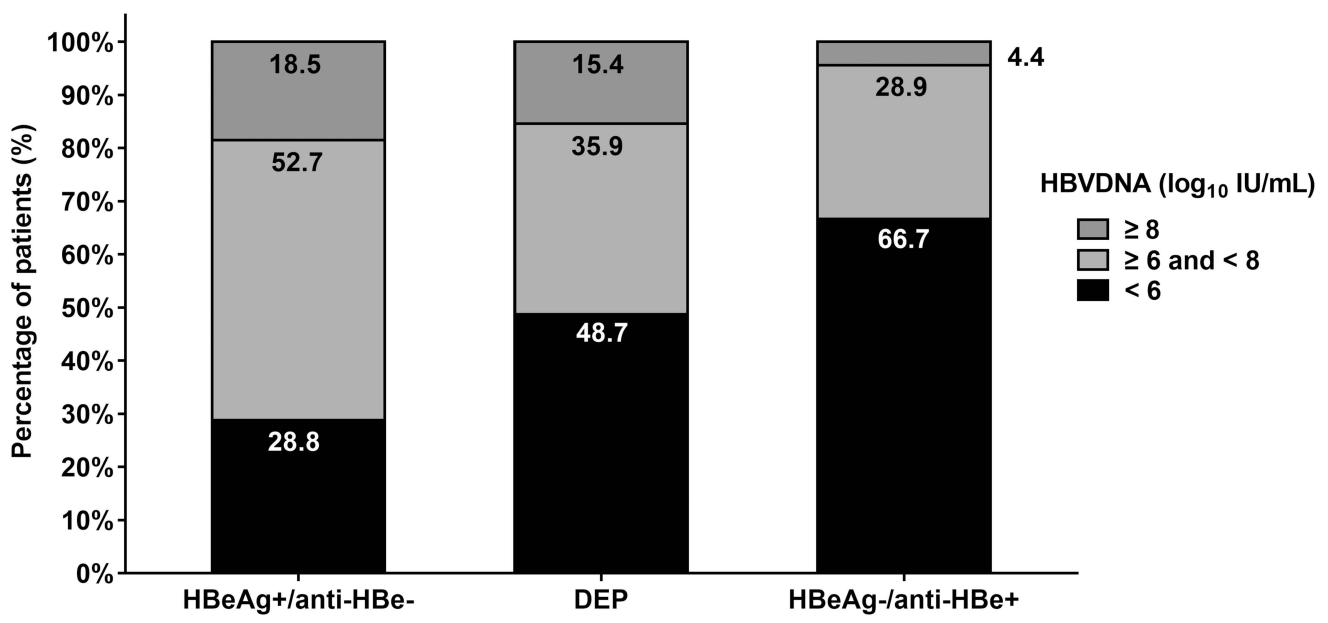

Figure 3 Distribution of DEP, $\mathrm{HBeAg}+/ a n t i-H B e-$, and $\mathrm{HBeAg}-/$ anti-HBe+ groups in association with HBV DNA level. (A) C-HBVI cases. (B) C-HBVI cases in the immuneactive phase.

Abbreviations: DEP, dual-positivity for both hepatitis $B$ e antigen and hepatitis $B$ e antibody; $C-H B V I$, chronic hepatitis $B$ virus infection; $H B V$, hepatitis $B$ virus; $H B e A g$, hepatitis B e antigen; anti-HBe, hepatitis B e antibody.

0.001, respectively; $\mathrm{HBeAg-/anti-HBe+,} 24.8 \%$ and $25.7 \%$, $\mathrm{P}=0.025$ and 0.015 , respectively). Furthermore, the proportion of ACLF in the DEP group $(7.9 \%, 13 / 165)$ was higher than that in the $\mathrm{HBeAg}+/$ anti-HBe- group $(1.6 \%, \mathrm{P}<0.001)$ and $\mathrm{HBeAg}$-/anti-HBe+ group $(2.9 \%, \mathrm{P}=0.001)$.

In the I-AP, the proportions of cirrhosis (30.8\%), decompensated cirrhosis (20.5\%), and ACLF (10.3\%) in the DEP group were greater than those in the $\mathrm{HBeAg}$ +/anti-HBe- group ( $\mathrm{P}=0.015,0.004$, and 0.003, respectively), while they were not significantly different between the DEP group and the $\mathrm{HBeAg}-/$ anti-HBe+ group $(\mathrm{P}=$ $0.821,0.590$, and 0.512 , respectively).

\section{Factors Associated with LF and ACLF}

Evaluation of APRI and FIB-4 scores was conducted using ULS and MLS analyses. MLS analysis demonstrated that DEP was associated with both APRI $>1.5(P=0.002$, odds ratio $(\mathrm{OR})=1.96,95 \% \mathrm{CI}: 1.27-3.03)$ and $\mathrm{FIB}-4>$ $1.45(P=0.003, \mathrm{OR}=2.07,95 \% \mathrm{CI}: 1.28-3.34)$ (Table 4). Gender, higher HBV DNA level, history of alcohol consumption, history of antiviral treatment and I-AP were independently associated with APRI $>1.5$, while age $\geq 45$ years old, gender, history of alcohol consumption, history of antiviral treatment, and I-AP were independently associated with FIB-4 $>1.45$. 
Table 4 Factors Associated with APRI $\geq 1.5$ and FIB-4 > I.45 in C-HBVI Cases

\begin{tabular}{|c|c|c|c|c|c|c|c|c|}
\hline & \multicolumn{4}{|c|}{ APRI $\geq I .5$} & \multicolumn{4}{|c|}{ FIB-4 > I.45 } \\
\hline & \multicolumn{2}{|c|}{ Univariate } & \multicolumn{2}{|c|}{ Multivariate } & \multicolumn{2}{|c|}{ Univariate } & \multicolumn{2}{|c|}{ Multivariate } \\
\hline & OR $(95 \% \mathrm{CI})$ & $\mathbf{P}$ & OR (95\% Cl) & $\mathbf{P}$ & OR (95\% Cl) & $\mathbf{P}$ & OR $(95 \% \mathrm{CI})$ & $\mathbf{P}$ \\
\hline $\begin{array}{l}\text { HBeAg/anti-HBe status } \\
\text { HBeAg+/anti-HBe- } \\
\text { DEP } \\
\text { HBeAg-/anti-HBe+ }\end{array}$ & $\begin{array}{c}\text { I } \\
\text { I.72(I.I7-2.52) } \\
0.59(0.48-0.73)\end{array}$ & $\begin{array}{c}<0.00 I \\
0.005 \\
<0.001\end{array}$ & $\begin{array}{c}1 \\
1.96(1.27-3.03) \\
0.88(0.68-1.14)\end{array}$ & $\begin{array}{l}0.001 \\
0.002 \\
0.319\end{array}$ & $\begin{array}{c}1 \\
2.06(1.32-3.21) \\
1.43(1.15-1.78)\end{array}$ & $\begin{array}{l}<0.001 \\
0.001 \\
0.001\end{array}$ & $\begin{array}{c}\mathrm{I} \\
2.07(1.28-3.34) \\
\mathrm{I} .12(0.86-1.44)\end{array}$ & $\begin{array}{l}0.012 \\
0.003 \\
0.401\end{array}$ \\
\hline $\begin{array}{l}\text { Age (years old) } \\
\quad<45 \\
\quad \geq 45\end{array}$ & $\begin{array}{c}\text { I } \\
0.70(0.59-0.85)\end{array}$ & $<0.001$ & & & $\begin{array}{c}\text { I } \\
4.28(3.47-5.28)\end{array}$ & $<0.001$ & $\begin{array}{c}\mathrm{I} \\
5.64(4.44-7.16)\end{array}$ & $<0.001$ \\
\hline $\begin{array}{l}\text { Gender } \\
\text { Female } \\
\text { Male }\end{array}$ & $\frac{1}{1.61(1.30-1.99)}$ & $<0.001$ & $\begin{array}{c}1 \\
1.35(1.06-1.71)\end{array}$ & 0.014 & $\begin{array}{c}\mathrm{I} \\
1.35(1.03-1.67)\end{array}$ & 0.006 & $\begin{array}{c}\mathrm{I} \\
1.30(1.02-1.65)\end{array}$ & 0.031 \\
\hline $\begin{array}{l}\text { HBV DNA }\left(\log _{10} \mathrm{IU} / \mathrm{mL}\right) \\
\text { Undetectable } \\
>\text { undetectable and }<4 \\
\geq 4 \text { and }<6 \\
\geq 6\end{array}$ & $\begin{array}{c}1 \\
1.67(1.26-2.22) \\
2.90(2.23-3.78) \\
5.04(3.85-6.60)\end{array}$ & $\begin{array}{l}<0.001 \\
<0.001 \\
<0.001 \\
<0.001\end{array}$ & $\begin{array}{c}1 \\
1.32(0.97-1.80) \\
0.83(0.57-1.23) \\
1.19(0.77-1.83)\end{array}$ & $\begin{array}{l}0.018 \\
0.078 \\
0.354 \\
0.441\end{array}$ & $\begin{array}{c}1 \\
0.87(0.66-1.13) \\
1.34(1.02-1.76) \\
1.00(0.77-1.30)\end{array}$ & $\begin{array}{l}0.031 \\
0.295 \\
0.036 \\
0.993\end{array}$ & & \\
\hline $\begin{array}{l}\text { Alcohol consumption } \\
\text { No } \\
\text { Yes }\end{array}$ & $\begin{array}{c}1 \\
2.97(1.91-4.61)\end{array}$ & $<0.001$ & $\begin{array}{c}\mathrm{I} \\
3.64(2.23-5.94)\end{array}$ & $<0.001$ & $\begin{array}{c}1 \\
4.12(2.06-8.27)\end{array}$ & $<0.001$ & $\begin{array}{c}\mathrm{I} \\
4.15(1.97-8.75)\end{array}$ & $<0.001$ \\
\hline $\begin{array}{l}\mathrm{HBsAg}(\mathrm{IU} / \mathrm{mL}) \\
\quad \leq 150 \\
\quad>150\end{array}$ & $\begin{array}{c}1 \\
1.40(1.14-1.73)\end{array}$ & 0.002 & & & $\begin{array}{c}\mathrm{I} \\
\mathrm{I} .07(0.86-1.33)\end{array}$ & 0.536 & & \\
\hline $\begin{array}{l}\text { Treatment history } \\
\text { No } \\
\text { Yes }\end{array}$ & $\begin{array}{c}1 \\
1.23(1.00-1.50)\end{array}$ & 0.051 & $\begin{array}{c}\mathrm{I} \\
\mathrm{I} .83(1.43-2.33)\end{array}$ & $<0.001$ & $\begin{array}{c}1 \\
2.11(1.66-2.67)\end{array}$ & $<0.001$ & $\begin{array}{c}1 \\
2.40(1.84-3.12)\end{array}$ & $<0.001$ \\
\hline $\begin{array}{l}\text { Immune-active } \\
\text { No } \\
\text { Yes }\end{array}$ & $\begin{array}{c}\text { I } \\
5.93(4.83-7.27)\end{array}$ & $<0.001$ & $\begin{array}{c}\mathrm{I} \\
6.73(4.89-9.25)\end{array}$ & $<0.001$ & $\begin{array}{c}1 \\
1.64(1.33-2.03)\end{array}$ & $<0.001$ & $\begin{array}{c}\mathrm{I} \\
3.00(2.33-3.87)\end{array}$ & $<0.001$ \\
\hline
\end{tabular}

Abbreviations: DEP, dual-positivity for both hepatitis $B$ e antigen and hepatitis $B$ e antibody; $\mathrm{C}-\mathrm{HBVl}$, chronic hepatitis $\mathrm{B}$ virus infection; $\mathrm{HBV}$, hepatitis $\mathrm{B}$ virus; $\mathrm{HBeAg}$, hepatitis B e antigen; anti-HBe, hepatitis B e antibody; HBsAg, hepatitis B surface antigen; APRI, AST-to-platelet ratio index; FIB-4, fibrosis-4.

ACLF was also evaluated by ULS and MLS analyses (Table 5). ULS analysis indicated that ACLF was associated with DEP, gender (male), history of alcohol consumption, history of antiviral treatment, I-AP, and a higher HBV DNA level. MLS analysis revealed that DEP (P < $0.001, \mathrm{OR}=4.80,95 \% \mathrm{CI}: 2.02-11.39)(\mathrm{HBeAg}+/ \mathrm{anti}-$ HBe- as reference group), gender (male) $(\mathrm{P}=0.016, \mathrm{OR}=$ 2.32, 95\% CI: 1.17-4.60), a higher HBV DNA level, history of antiviral treatment $(\mathrm{P}=0.003, \mathrm{OR}=2.10$, 95\% CI: $1.28-3.46)$, and I-AP $(\mathrm{P}=0.008, \mathrm{OR}=2.57$, 95\% CI: $1.29-5.15)$ were independently associated with ACLF.

\section{Discussion}

In this cross-sectional study, the prevalence of DEP among C-HBVI cases was 5.9\% (165/2820), which was higher than the previously reported rate. ${ }^{3,5}$ The prevalence of DEP in the immune-tolerant phase and I-AP was $5.7 \%$ and $10.7 \%$, respectively, and the latter was similar to the rate mentioned in a previous study $(10.4 \%){ }^{4}$ The prevalence of cases in the I-AP among DEP patients was $56.9 \%$ (78/137), which was higher than the rate $(42 \%)$ in immune-clearance phase reported in advance. ${ }^{3}$

The age of dual-positive cases fell between that of the HBeAg+/anti-HBe- and HBeAg-/anti-HBe+ groups, 
Table 5 Factors Associated with ACLF in C-HBVI Cases

\begin{tabular}{|c|c|c|c|c|}
\hline & \multicolumn{4}{|c|}{ ACLF } \\
\hline & \multicolumn{2}{|c|}{ Univariate } & \multicolumn{2}{|c|}{ Multivariate } \\
\hline & OR $(95 \% \mathrm{CI})$ & $\mathbf{P}$ & OR $(95 \% \mathrm{Cl})$ & $\mathbf{P}$ \\
\hline $\begin{array}{l}\text { HBeAg/anti-HBe status } \\
\text { HBeAg+/anti-HBe- } \\
\text { DEP } \\
\text { HBeAg-/anti-HBe+ }\end{array}$ & $\begin{array}{c}1 \\
5.34(2.29-12.45) \\
2.24(1.13-4.45)\end{array}$ & $\begin{array}{c}0.001 \\
<0.001 \\
0.021\end{array}$ & $\begin{array}{c}1 \\
4.80(2.02-11.39) \\
2.58(1.24-5.37)\end{array}$ & $\begin{array}{c}0.002 \\
<0.001 \\
0.011\end{array}$ \\
\hline $\begin{array}{l}\text { Age (years old) } \\
\quad<45 \\
\quad \geq 45\end{array}$ & $\begin{array}{c}\text { I } \\
1.07(0.67-1.72)\end{array}$ & 0.765 & & \\
\hline $\begin{array}{c}\text { Gender } \\
\text { Female } \\
\text { Male }\end{array}$ & $\frac{1}{2.66(I .36-5.2 I)}$ & 0.004 & $\frac{1}{2.32(1.17-4.60)}$ & 0.016 \\
\hline $\begin{array}{l}\text { HBVDNA }\left(\log _{10} 1 \mathrm{IU} / \mathrm{mL}\right. \\
\text { Undetectable } \\
<4 \\
\geq 4 \text { and }<6 \\
\geq 6\end{array}$ & $\begin{array}{c}1 \\
3.33(1.60-6.91) \\
2.95(1.43-6.10) \\
2.17(1.01-4.69)\end{array}$ & $\begin{array}{l}0.008 \\
0.001 \\
0.003 \\
0.048\end{array}$ & $\begin{array}{c}1 \\
3.22(1.49-6.97) \\
1.76(0.67-4.61) \\
1.43(0.49-4.20)\end{array}$ & $\begin{array}{c}0.011 \\
0.003 \\
0.25 \\
0.515\end{array}$ \\
\hline $\begin{array}{l}\text { Alcohol consumption } \\
\text { No } \\
\text { Yes }\end{array}$ & $\frac{1}{2.52(1.17-5.42)}$ & 0.018 & & \\
\hline $\begin{array}{l}\mathrm{HBsAg}(\mathrm{IU} / \mathrm{mL}) \\
\quad \leq 150 \\
\quad>150\end{array}$ & $\begin{array}{c}\mathrm{I} \\
0.73(0.45-1.18)\end{array}$ & 0.2 & & \\
\hline $\begin{array}{l}\text { Treatment history } \\
\text { No } \\
\text { Yes }\end{array}$ & $\begin{array}{c}\mathrm{I} \\
\mathrm{I.7I}(1.06-2.74)\end{array}$ & 0.027 & $\begin{array}{c}1 \\
2.10(1.28-3.46)\end{array}$ & 0.003 \\
\hline $\begin{array}{l}\text { Immune-active } \\
\text { No } \\
\text { Yes }\end{array}$ & $\begin{array}{c}1 \\
2.24(1.41-3.58)\end{array}$ & 0.001 & $\begin{array}{c}\text { I } \\
2.57(1.29-5.15)\end{array}$ & 0.008 \\
\hline
\end{tabular}

Abbreviations: DEP, dual-positivity for both hepatitis $B$ e antigen and hepatitis $B$ e antibody; $C-H B V I$, chronic hepatitis $B$ virus infection; $H B V$, hepatitis $B$ virus; $H B e A$, hepatitis $B$ e antigen; anti-HBe, hepatitis $B$ e antibody; $\mathrm{HBs} A$, hepatitis $B$ surface antigen; ACLF, acute-on-chronic liver failure.

indicating that DEP might occur before the seroconversion of HBV. The levels of ALT, AST, and TBIL in the DEP group were higher than those in the $\mathrm{HBeAg}$ mono-positive and anti-HBe mono-positive groups, while the ALB level was lower than that in the control group. Compared with the control group, DEP cases had higher INR and D-dimer level, while lower PLT count and fibrinogen level, demonstrating that DEP had a certain degree of coagulation dysfunction and a low level of fibrinolysis, which might lead to organ failure. ${ }^{11,12}$ The HBV DNA level in the DEP group fell between that in the $\mathrm{HBeAg}$ mono-positive and anti-HBe mono-positive groups. As a high ALT level, a low HBV DNA level, and advanced LF are predictive factors for $\mathrm{HBeAg}$ seroconversion, ${ }^{13}$ the serological results may suggest that the period of DEP precedes serological conversion.

In the present study, we also found that DEP was closely associated with advanced LF and ACLF. Our data demonstrated that there was a remarkably higher incidence of LF, cirrhosis, and ACLF in DEP cases with $\mathrm{C}$-HBVI than in HBeAg mono-positive cases, which is in agreement with the results of a previous research. ${ }^{4}$ However, this higher incidence was also observed in DEP cases compared with that in anti-HBe mono- 
positive cases, suggesting that the detection of DEP may be associated with the progression of LDs.

Among C-HBVI cases in the I-AP, DEP cases had higher values of biochemical indices of liver function, including ALT and TBIL titers, as well as APRI and FIB-4 scores, than $\mathrm{HBeAg}+/$ anti-HBe- cases. DEP cases in the I-AP mainly suffered from more severe liver dysfunction, while the FIB-4 scores and the proportions of cirrhosis and ACLF were similar to those in anti-HBe mono-positive cases in the I-AP, which is consistent with the findings of a previous research. ${ }^{4}$ However, the APRI score was higher in DEP cases than that in anti-HBe mono-positive cases. This inconsistency might be due to the lack of consideration of age in the calculation of APRI score, which might increase the effects of the agedependent differences on the prediction of LF between the two groups.

The mechanism underlying the association between DEP and more severe LDs might include the occurrence of $\mathrm{HBeAg} /$ anti-HBe and antigen-antibody complex ${ }^{14}$ in antigen-antibody reaction, as well as the accumulation of core promoter mutations in the I-AP.

First, in the process of seroconversion, along with the enhancement of anti-HBe level, the antibody and HBeAg coexist and generate antigen-antibody complex. The deposition of the immune complex may result in the stimulation of immune response and extrahepatic manifestations. ${ }^{15}$ Moreover, the secretion of cytokines by cytotoxic T-lymphocyte (CTL) intercepts viral replication and HBV gene expression, which accelerates spontaneous HBeAg seroconversion. ${ }^{16}$ Meanwhile, the enhancement of CTL may destroy hepatocytes and lead to temporary exacerbation of hepatitis before $\mathrm{HBeAg}$ seroconversion. ${ }^{17}$

Second, the double-mutation A1762T/G1764A in the basal core promoter $(\mathrm{BCP}) / \mathrm{X}$ overlap region was found to be one of the most common core promoter mutations, ${ }^{18}$ which was positively correlated with the levels of ALT and AST, ${ }^{19,20}$ the fluctuation of HBV DNA level, ${ }^{20,21}$ and the progression of $\mathrm{LDs},{ }^{22-25}$ and it can be a predictor of HBeAg-to-anti-HBe seroconversion. ${ }^{23}$ A previous research showed that this mutation might be selected through CTL escape during the loss of immune tolerance. ${ }^{26}$ It is speculated that in the I-AP, during the accumulation of core promoter mutations, the coexistence of BCP mutations and wild-type sequences might lead to the suppression of affinity between $\mathrm{HBeAg}$ and anti-HBe, thereby leading to the dual-positivity for $\mathrm{HBeAg}$ and antiHBe. This might explain the high levels of ALT and TBIL in DEP cases during seroconversion, and the elevated degree of LF was found to be similar to that in anti-HBe mono-positive cases in the I-AP along with the accumulation of mutations. However, this hypothesis cannot explain the phenomenon that cases with a low HBV DNA level $<2000 \mathrm{IU} / \mathrm{mL}$, who may be in the inactive phase, may have dual-positivity during the progression of LDs. This may be due to the reactivation of HBV, and longitudinal studies may provide more definitive evidence.

The limitations of this study should be pointed out. First, it was a cross-sectional study and lacked follow-up data of hospitalized cases. The recruited patients were all hospitalized cases, and certain differences with outpatients could not be excluded. The severity of cirrhosis was not evaluated, and the detailed disease course and treatment process were not accurately recorded to evaluate their effects on the LF and ACLF. Furthermore, the prevalence of DEP in Guangdong province might not be representative of that in the whole country (China) because of the uneven distribution of HBV genotypes. Moreover, the number of ACLF and LF patients in immune-tolerant phase was limited, which hindered us to perform the ULS and MLS analyses. A multicenter longitudinal study including genotyping is therefore required to elucidate the correlation between different genotypes.

\section{Conclusions}

In conclusion, DEP is infrequent among C-HBVI cases, and it is associated with hepatocyte and coagulation dysfunction and higher risks of LF and ACLF. The screening of DEP in $\mathrm{C}$-HBVI cases and subsequent active treatments are imperative.

\section{Ethical Approval}

This study was conducted in accordance with the Declaration of Helsinki. The Institutional Review Board (IRB) of Dongguan People's Hospital reviewed the protocol (KYKT2021-007) and waived the requirement for informed consent because anonymous data were analyzed retrospectively.

\section{Acknowledgments}

This manuscript was edited by a prestigious company, TopEdit (www.topeditsci.com), professionally working on English language editing services. 


\section{Author Contributions}

Reading and approving the submitted version of the manuscript could be undertaken by all the authors, who substantially participated in all the stages of the research. All authors made a significant contribution to the work reported, whether that is in the conception, study design, execution, acquisition of data, analysis and interpretation, or in all these areas; took part in drafting, revising or critically reviewing the article; gave final approval of the version to be published; have agreed on the journal to which the article has been submitted; and agree to be accountable for all aspects of the work.

\section{Funding}

This research was supported by the Local Innovation and Research Teams Project of Guangdong Pearl River Talents Program (Grant No. 2017BT01S131) and Sanming Project of Medicine in Shenzhen (Grant No. SZSM201911001).

\section{Disclosure}

The authors declare that there is no conflict of interest.

\section{References}

1. Terrault NA, Bzowej NH, Chang K-M, Hwang JP, Jonas MM, Murad MH. AASLD guidelines for treatment of chronic hepatitis B: hepatology, Month 2015. Hepatology. 2016;63(1):261-283. doi:10.1002/hep. 28156

2. Liu J, Liang W, Jing W, Liu M. Countdown to 2030: eliminating hepatitis B disease, China. Bull World Health Organ. 2019;97 (3):230-238. doi:10.2471/BLT.18.219469

3. Xiang Y, Chen P, Xia JR, Zhang LP. A large-scale analysis study on the clinical and viral characteristics of hepatitis $\mathrm{B}$ infection with concurrence of hepatitis B surface or E antigens and their corresponding antibodies. Gene Mol Res. 2017;16(1). doi:10.4238/gmr16019102

4. Wang J, Zhou B, Lai Q, et al. Clinical and virological characteristics of chronic hepatitis B with concurrent hepatitis B e antigen and antibody detection: concurrent circulation of HBeAg and anti-Hbe. $J$ Viral Hepat. 2011;18(9):646-652. doi:10.1111/j.1365-2893.2010.01345.x

5. Lim CK, Tan JTM, Khoo JBS, et al. Correlations of HBV genotypes, mutations affecting $\mathrm{HBeAg}$ expression and $\mathrm{HBeAg}$ / anti-HBe status in HBV carriers. Int J Med Sci. 2006;3(1):14-20. doi:10.7150/ijms.3.14

6. Terrault NA, Lok ASF, McMahon BJ, et al. Update on prevention, diagnosis, and treatment of chronic hepatitis B: AASLD 2018 hepatitis B guidance. Hepatology. 2018;67(4):1560-1599. doi:10.1002/ hep. 29800

7. Sarin SK, Choudhury A, Sharma MK, et al. Acute-on-chronic liver failure: consensus recommendations of the Asian Pacific association for the study of the liver (APASL): an update. Hepatol Int. 2019;13 (4):353-390. doi:10.1007/s12072-019-09946-3

8. Sterling RK, Lissen E, Clumeck N, et al. Development of a simple noninvasive index to predict significant fibrosis in patients with HIV/ HCV coinfection. Hepatology. 2006;43(6):1317-1325. doi:10.1002/ hep. 21178

9. Wai C-T, Greenson JK, Fontana RJ, et al. A simple noninvasive index can predict both significant fibrosis and cirrhosis in patients with chronic hepatitis C. Hepatology. 2003;38(2):518-526. doi:10.1053/ jhep.2003.50346
10. World Health Organization. Guidelines for the Prevention, Care and Treatment of Persons with Chronic Hepatitis B Infection; 2015.

11. Blasi A, Calvo A, Prado V, et al. Coagulation failure in patients with acute-on-chronic liver failure and decompensated cirrhosis: beyond the international normalized ratio. Hepatology. 2018;68 (6):2325-2337. doi:10.1002/hep.30103

12. Chen J, Duan Z-P, Bai L, et al. [Changing characteristic of blood coagulation factors and their correlation with blood coagulation status in different hepatic diseases]. Zhonghua Gan Zang Bing Za Zhi. 2012;20(3):206-210. doi:10.3760/cma.j.issn.1007-3418.2012.03.014. [Chinese].

13. Lin B, Ha NB, Liu A, et al. Low incidence of hepatitis B e antigen seroconversion in patients treated with oral nucleos(t)ides in routine practice. J Gastroenterol Hepatol. 2013;28(5):855-860. doi:10.1111/ jgh. 12108

14. Reverberi R, Reverberi L. Factors affecting the antigen-antibody reaction. Blood Transfus. 2007;5(4):227-240. doi:10.2450/ 2007.0047-07

15. Wiggelinkhuizen J, Sinclair-Smith C, Stannard LM, Smuts H. Hepatitis B virus associated membranous glomerulonephritis. Arch Dis Child. 1983;58(7):488-496. doi:10.1136/adc.58.7.488

16. Liaw Y-F. Hepatitis flares and hepatitis B e antigen seroconversion: implication in anti-hepatitis B virus therapy. $J$ Gastroenterol Hepatol. 2003;18(3):246-252. doi:10.1046/j.1440-1746.2003.02976.x

17. Liaw YF, Chu CM, Su IJ, Huang MJ, Lin DY, Chang-Chien CS. Clinical and histological events preceding hepatitis B e antigen seroconversion in chronic type B hepatitis. Gastroenterology. 1983;84 (2):216-219. doi:10.1016/S0016-5085(83)80114-0

18. Yoo BC, Park J-W, Kim HJ, Lee DH, Cha YJ, Park SM. Precore and core promoter mutations of hepatitis $\mathrm{B}$ virus and hepatitis $\mathrm{B}$ e antigen-negative chronic hepatitis B in Korea. J Hepatol. 2003;38 (1):98-103. doi:10.1016/s0168-8278(02)00349-5

19. Sayed SK, Kobeisy MA. The relationship between core promoter mutation of hepatitis B virus, viral load and hepatitis B e antigen status in chronic hepatitis B patients. Cell Immunol. 2012;276(12):35-41. doi:10.1016/j.cellimm.2012.03.003

20. Silva Souza ACD, Souza Marasca GD, Kretzmann-Filho NA, et al. Identification of hepatitis B virus A1762T/G1764A double mutant strain in patients in Southern Brazil. Braz J Infect Dis. 2017;21 (5):525-529. doi:10.1016/j.bjid.2017.05.002

21. Fang Z-L, Sabin CA, Dong B-Q, et al. The association of HBV core promoter double mutations (A1762T and G1764A) with viral load differs between $\mathrm{HBeAg}$ positive and anti-HBe positive individuals: a longitudinal analysis. J Hepatol. 2009;50(2):273-280. doi:10.1016/ j.jhep.2008.09.014

22. Hannoun C, Horal P, Lindh M. Long-term mutation rates in the hepatitis B virus genome. J Gen Virol. 2000;81(Pt 1):75-83. doi:10.1099/0022-1317-81-1-75

23. Wei F, Zheng Q, Li M, Wu M. The association between hepatitis $\mathrm{B}$ mutants and hepatocellular carcinoma: a meta-analysis. Medicine. 2017;96(19):e6835. doi:10.1097/MD.0000000000006835

24. Chen Y-H, Lu S-N, Wang J-H, Hung C-H, Hu T-H, Chen C-H. Pre-S/ surface and core promoter/precore mutations in chronic hepatitis B patients with severe acute exacerbation. Dig Dis Sci. 2019;64 (9):2563-2569. doi:10.1007/s10620-019-05571-0

25. Yang Z, Zhuang L, Lu Y, Xu Q, Tang B, Chen X. Naturally occurring basal core promoter A1762T/G1764A dual mutations increase the risk of HBV-related hepatocellular carcinoma: a meta-analysis. Oncotarget. 2016;7(11):12525-12536. doi:10.18632/oncotarget.7123

26. Pawlotsky JM. The concept of hepatitis B virus mutant escape. J Clin Oncol. 2005;34(Suppl 1):S125-S129. doi:10.1016/s1386-6532(05) 80021-6 


\section{Publish your work in this journal}

The International Journal of General Medicine is an international, peer-reviewed open-access journal that focuses on general and internal medicine, pathogenesis, epidemiology, diagnosis, monitoring and treatment protocols. The journal is characterized by the rapid reporting of reviews, original research and clinical studies across all disease areas. The manuscript management system is completely online and includes a very quick and fair peer-review system, which is all easy to use. Visit http://www.dovepress.com/ testimonials.php to read real quotes from published authors. 